\title{
Enhanced Efficiency of Dye-Sensitized Solar Cells by Trace Amount Ca-Doping in $\mathrm{TiO}_{2}$ Photoelectrodes
}

\author{
Mengmei Pan, Hanjun Liu, Zhongyu Yao, and Xiaoli Zhong \\ School of Physics and Electronic Engineering, Hainan Normal University, Haikou, Hainan 571158, China \\ Correspondence should be addressed to Hanjun Liu; liuhanjun76@163.com
}

Received 9 August 2014; Accepted 8 September 2014

Academic Editor: Xiaohu Huang

Copyright (C) 2015 Mengmei Pan et al. This is an open access article distributed under the Creative Commons Attribution License, which permits unrestricted use, distribution, and reproduction in any medium, provided the original work is properly cited.

\begin{abstract}
Trace amount $\mathrm{Ca}$-doped $\mathrm{TiO}_{2}$ films were synthesized by the hydrothermal method and applied as photoanodes of dye-sensitized solar cells (DSSCs). To prepare Ca-doped $\mathrm{TiO}_{2}$ film electrodes, several milliliters of $\mathrm{Ca}\left(\mathrm{NO}_{3}\right)_{2}$ solution was added in $\mathrm{TiO}_{2}$ solution during the hydrolysis process. The improvements of DSSCs were confirmed by photocurrent density-voltage $(J-V)$ characteristics, electrochemical impedance spectroscopy (EIS) measurements. Owing to the doping effect of Ca, the Ca-doped $\mathrm{TiO}_{2}$ thin film shows power conversion efficiency of $7.45 \%$ for $50 \mathrm{ppm} \mathrm{Ca-doped} \mathrm{TiO}_{2}$ electrode, which is higher than that of the undoped $\mathrm{TiO}_{2}$ film $(6.78 \%)$ and the short-circuit photocurrent density $\left(J_{\mathrm{sc}}\right)$ increases from 13.68 to $15.42 \mathrm{~mA} \cdot \mathrm{cm}^{-2}$. The energy conversion efficiency and short-circuit current density $\left(J_{\text {sc }}\right)$ of DSSCs were increased due to the faster electron transport in the Ca-doped $\mathrm{TiO}_{2}$ film. When $\mathrm{Ca}$ was incorporated into $\mathrm{TiO}_{2}$ films, the electrons transport faster and the charge collection efficiency $\eta_{\mathrm{cc}}$ is higher than that in the undoped $\mathrm{TiO}_{2}$ films.
\end{abstract}

\section{Introduction}

Dye-sensitized solar cells (DSSCs) based on mesoporous nanocrystalline $\mathrm{TiO}_{2}$ film have achieved photoelectric conversion efficiency $(\eta)$ up to $13 \%$. In order to develop high performance of DSSCs and commercialize successfully, many nanocrystalline semiconductors such as $\mathrm{TiO}_{2}$ [1], $\mathrm{ZnO}$ [2], and $\mathrm{SnO}_{2}$ [3] have been used as photoanode materials. Among them, $\mathrm{TiO}_{2}$ has been proven to be the best semiconductor electrode material due to its high chemical stability [4], excellent charge transport capability, and ideal position of the conduction band edge. It is known to be one of the main components of DSSCs and plays a key role in determining the performance of DSSCs.

In recent years, Doping has been considered as a promising way to improve the properties of $\mathrm{TiO}_{2}$ photoanode. $\mathrm{TiO}_{2}$ films doped with metal and nonmetal have been extensively researched, such as Mg-doping [5], La-doping [6], $\mathrm{Nb}$ doping [7], Ta-doping [8], and $\mathrm{N}$-doping [9], which may increase the photoelectric conversion efficiency. In all the applications mentioned above, the $\mathrm{TiO}_{2}$ films were doped at very high levels (from $0.1 \%$ to $10 \%$ ). However, few studies have been reported about $\mathrm{TiO}_{2}$ doped at parts per million (ppm) level applied as photoanode of DSSCs. Xie et al. [10] have found that trace amount of Cr-doping $\mathrm{TiO}_{2}$ films could improve the efficiency of DSSCs. The improvement was ascribed to $\mathrm{Cr}$ additions offers more electrons for $\mathrm{TiO}_{2}$ and increases the property of electron transport for DSSCs. As we all know, doping semiconductors at parts per million (ppm) level is the most common approach for enhancing the Fermi energy level of semiconductors and then increasing their conductivity (for instance, $\mathrm{Si}$ ).

In this paper, a series of Ca-doped $\mathrm{TiO}_{2}$ films were synthesized by hydrothermal method and were successfully applied as the photoanode materials in DSSCs, and the shortcircuit current densities $\left(J_{\mathrm{sc}}\right)$ and photoelectric conversion efficiencies of DSSCs were found to be increased by trace amount doping in $\mathrm{TiO}_{2}$. The change in performance of DSSCs employing Ca-doped $\mathrm{TiO}_{2}$ films with different concentrations was obvious. We can conclude that the intrinsic increases in the photocurrent and photoelectric conversion efficiency are primarily related to faster electron transport in the Ca-doped $\mathrm{TiO}_{2}$ film. The effects caused by Ca doping on electron collection, transfer, and recombination of the DSSCs are discussed below. 


\section{Experimental Section}

2.1. Preparation of Undoped $\mathrm{TiO}_{2}$ and $\mathrm{Ca}$-Doped $\mathrm{TiO}_{2}$ Pastes. Titanium isopropoxide (TTIP) was used as $\mathrm{Ti}$ precursors and calcium nitrate $\left(\mathrm{Ca}\left(\mathrm{NO}_{3}\right)_{2} \cdot 4 \mathrm{H}_{2} \mathrm{O}\right)$ was the $\mathrm{Ca}$ sources. Pure $\mathrm{TiO}_{2}$ and $\mathrm{Ca}$-doped $\mathrm{TiO}_{2}$ pastes were synthesized by a hydrothermal treatment method. The hydrothermal solutions were synthesized as follows [11].

(i) $2.1 \mathrm{~g}$ acetic acid was added dropwise into $10 \mathrm{~mL}$ of TTIP. Subsequently, the mixture was added to $50 \mathrm{~mL}$ of deionized water mixed with different amounts of $\mathrm{Ca}\left(\mathrm{NO}_{3}\right)_{2} \cdot 4 \mathrm{H}_{2} \mathrm{O}\left(\mathrm{Ca} / \mathrm{TiO}_{2}\right.$ molar ratio: undoped, $20 \mathrm{ppm}, 50 \mathrm{ppm}, 70 \mathrm{ppm}$, and $100 \mathrm{ppm}$ ) with rapid stirring for $1 \mathrm{~h}$. Then, $0.68 \mathrm{~mL}$ of nitric acid was added to the obtained mixture solution. After continuous stirring at $80^{\circ} \mathrm{C}$ for $2 \sim 3 \mathrm{~h}$, a transparent mixture solution was obtained.

(ii) The transparent mixture solution was filtered to remove insoluble impurities and transferred into an autoclave at $220^{\circ} \mathrm{C}$ for $12 \mathrm{~h}$. After cooling to room temperature, $0.4 \mathrm{~mL}$ of nitric acid was added into the colloid, using ultrasonicator to disperse.

(iii) The colloid was concentrated to $20 \mathrm{~mL}$ by rotary evaporator. Finally, PEG and Triton X-100 were added to form $\mathrm{TiO}_{2}$ paste. The obtained pastes were denoted as undoped $\mathrm{TiO}_{2}$, Ca-1: 20 ppm Ca-doped $\mathrm{TiO}_{2}, \mathrm{Ca}$ 2: 50 ppm Ca-doped $\mathrm{TiO}_{2}$, Ca-3: 70 ppm Ca-doped $\mathrm{TiO}_{2}$, and Ca-4: 100 ppm Ca-doped $\mathrm{TiO}_{2}$.

Following the procedure described, a total of five pastes with different concentrations of Ca were prepared.

2.2. Fabrication of Photoelectrodes and DSSCs. The FTO glass was used as substrate after careful cleaning. The pure $\mathrm{TiO}_{2}$ and $\mathrm{Ca}$-doped $\mathrm{TiO}_{2}$ pastes were coated onto FTO substrates using a doctor-blade method, respectively. Next, the photoelectrodes were sintered at $500^{\circ} \mathrm{C}$ for $30 \mathrm{~min}$ to obtain the mesoporous $\mathrm{TiO}_{2}$ film photoelectrodes. The thicknesses of these films were around $8 \mu \mathrm{m}$ measured with a TalyForm S4C-3D profilometer. They were dipped into a $0.5 \mathrm{mM}$ N719 dye solution for $24 \mathrm{~h}$ at room temperature, and the excessive dye was washed away by using ethanol, followed by drying at $60^{\circ} \mathrm{C}$. The platinum-coated FTO was used as the counter. A drop of electrolyte solution was injected into the photoelectrode and then the counter was clamped onto the photoelectrode; the electrolyte solution consisted of $0.05 \mathrm{mM}$ LiI, 0.03 $\mathrm{M} \mathrm{I}_{2}$, 0.1 M PMII (1-methyl-3-propyl imidazolium iodide), 0.1 M GNCS, and 0.5 M TBP in mixed solvent of acetonitrile and PC (volume ratio: 1/1). A sandwich-type DSSC configuration was fabricated.

2.3. Measurements. Photovoltaic measurements were performed by a CHI660C electrochemical workstation $(\mathrm{CH}$ Instruments, Shanghai, China) at room temperature. The irradiated area of each cell was kept at $0.25 \mathrm{~cm}^{2}$ by using a light-tight metal mask. Electrochemical impedance spectroscopy (EIS) technique [12] was employed to investigate the electron transport in DSSCs.

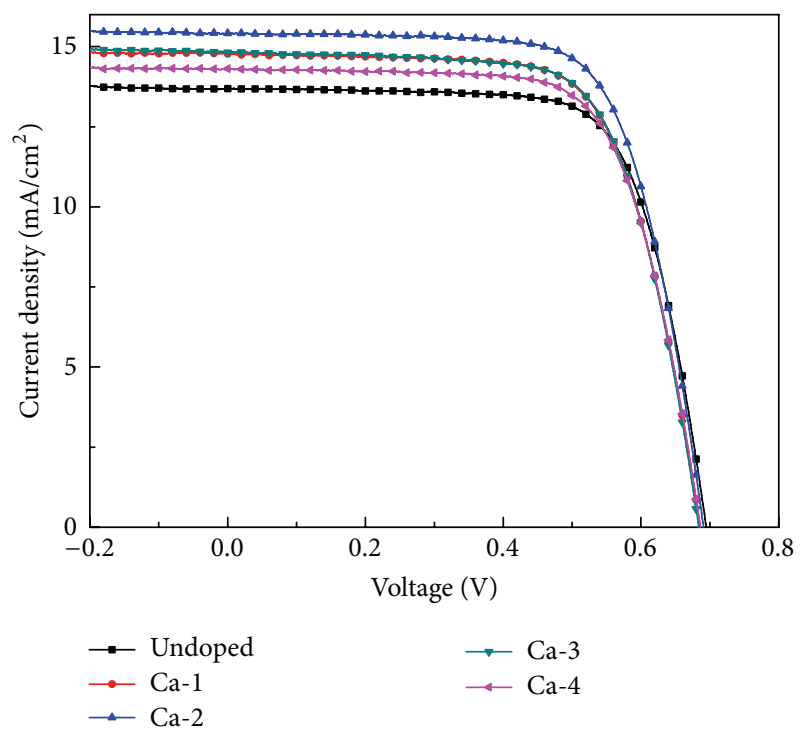

FIGURE 1: $J-V$ characteristics of DSSCs based on the undoped and Ca-doped $\mathrm{TiO}_{2}$ photoanodes.

\section{Results and Discussion}

3.1. J-V Characteristics. The photocurrent density-voltage $(J-V)$ characteristics of the DSSCs based on the pure $\mathrm{TiO}_{2}$ film photoelectrodes and $\mathrm{Ca}$-doped $\mathrm{TiO}_{2}$ film photoelectrodes are shown in Figure 1. The average performance characteristics obtained from multiple cells with the same Ca content were summarized in Table 1, which shows the correlation between the photovoltaic performance parameters and the $\mathrm{Ca}$ content in the $\mathrm{TiO}_{2}$. The best photovoltaic performance was obtained from $50 \mathrm{ppm}$ Ca-doped $\mathrm{TiO}_{2}$. Obviously, as can be seen from the graph, the energy conversion efficiency $(\eta)$ went up with the increase of Ca content, which was attributed to the enhancement of the short-circuit current density $\left(J_{\mathrm{sc}}\right)$. The $J_{\mathrm{sc}}$ of DSSCs based on $50 \mathrm{ppm}$ Ca-doped $\mathrm{TiO}_{2}$ was $15.42 \mathrm{~mA} \cdot \mathrm{cm}^{-2}$, which was $12.7 \%$ higher than that of undoped cells. The energy conversion efficiency of $7.58 \%$ was achieved for cells based on 50 ppm Ca-doped $\mathrm{TiO}_{2}$ electrode, which accounts for $9.88 \%$ higher than that of undoped cells. The effect on open-circuit voltage $\left(V_{\text {oc }}\right)$ and fill factor as a result of such a little amount of $\mathrm{Ca}$-doping was negligible. The energy conversion efficiency $(\eta)$ increases gradually with the increase of $\mathrm{Ca}$ content and reaches an optimum value coinciding with $\mathrm{Ca}$ quantity of $50 \mathrm{ppm}$. However, the higher Ca amounts ( $>50 \mathrm{ppm})$ cause electron scattering and trap electrons which increase dark current. As a result, the energy conversion efficiency of DSSCs begin to fall.

3.2. Electrochemical Impedance Spectroscopy Analysis of DSSCs. To investigate the difference of the charge transport properties between pure DSSCs and Ca-doped DSSCs, we performed electrochemical impedance spectroscopy (EIS) analysis. EIS has been widely employed to investigate the electron transport in DSSCs, for example, measuring the respective time constants for charge combination and for the 
TABLE 1: Performance of DSSCs based on undoped and Ca-doped $\mathrm{TiO}_{2}$ photoanodes.

\begin{tabular}{lccccccc}
\hline DSSCs & Doping/ppm & $V_{\text {oc }} / \mathrm{mV}$ & $J_{\text {sc }} / \mathrm{mAcm}^{2}$ & FF & $\eta / \%$ & $R_{\mathrm{ct}} / \Omega$ & 7.34 \\
\hline Undoped & 0 & 695 & 13.68 & 0.71 & 6.78 & 0.75 \\
Ca-1 & 20 & 686 & 14.78 & 0.69 & 7.00 & 7.32 \\
Ca-2 & 50 & 691 & 15.42 & 0.70 & 7.45 & 5.24 \\
Ca-3 & 70 & 684 & 14.82 & 0.70 & 7.00 & 8.09 \\
Ca-4 & 100 & 686 & 14.32 & 0.69 & 6.84 & 0.80 \\
\hline
\end{tabular}

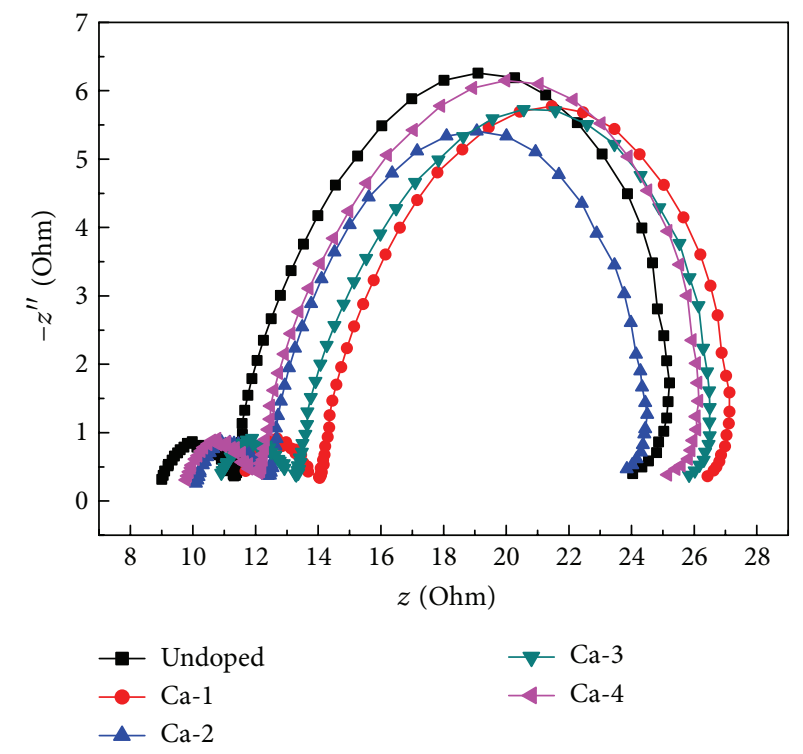

(a)
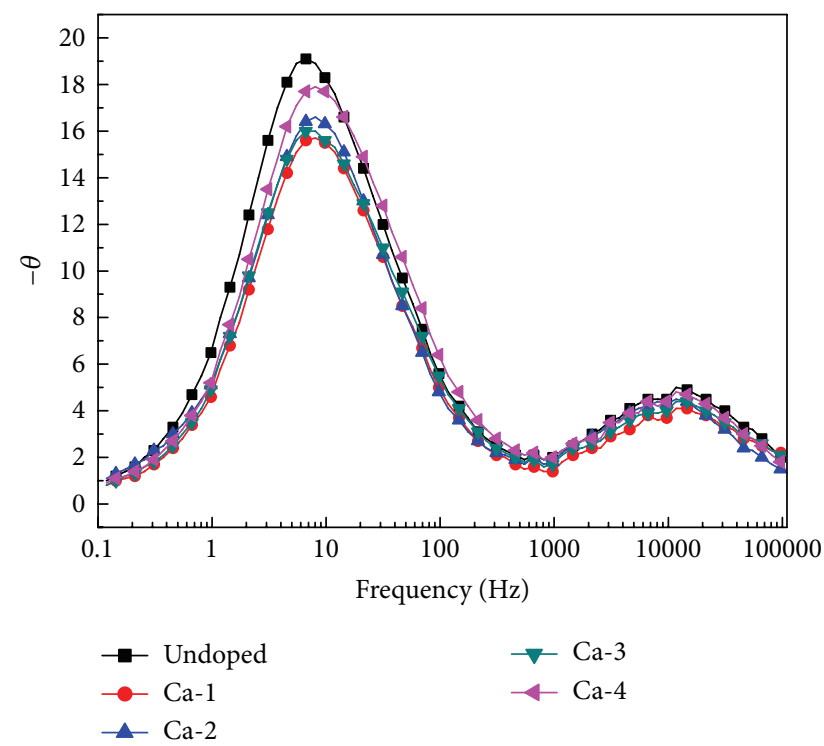

(b)

FIGURE 2: EIS of DSSCs based on the undoped and Ca-doped $\mathrm{TiO}_{2}$ photoanodes measured in the illumination at the applied bias of $V_{\text {oc }}$ (a) Nyquist plots and (b) Bode phase plots.

combined processes of charge collection. From the measured spectra of EIS, we can get reliable value of the parameter. Figure 2 shows the EIS spectra of pure DSSCs and Cadoped DSSCs, the impedance spectra of DSSCs based on the pure $\mathrm{TiO}_{2}$ and $\mathrm{Ca}$-doped $\mathrm{TiO}_{2}$ were measured from 0.1 to $10^{5} \mathrm{~Hz}$ in the illumination at the applied bias of $V_{\text {oc }}$. The spectra are composed of two semicircles: the small semicircle in the high frequency range of $10^{3}$ to $10^{5} \mathrm{~Hz}$ fitted to a charge transfer resistance $\left(R_{\mathrm{ct}}\right)$ at the interfaces of the redox electrolyte/Pt counter electrode and $\mathrm{FTO} / \mathrm{TiO}_{2}$ and the large semicircle in the frequency range of 1 to $10^{3} \mathrm{~Hz}$ fitted to a transport resistance $\left(R_{w}\right)$, which is related to the charge transport resistance of the accumulation/transport [13] of the injected electrons within $\mathrm{TiO}_{2}$ film and the charge transport resistance at the $\mathrm{TiO}_{2} /$ redox electrolyte interfaces. This large semicircle is the major concern here. As shown in Figure 2, the large semicircle got smaller with the increase of $\mathrm{Ca}$ in $\mathrm{TiO}_{2}$ films. This change reflected the acceleration of electron transport process in $\mathrm{TiO}_{2}$ photoanode. The modeled internal resistances of the DSSCs based on five different electrodes are exhibited in Table 2, in which $t_{r}$ is the electron transport time, $t_{c}$ is the electron lifetime, $R_{w}$ is charge transport resistance, and $\eta_{c c}$ is the charge collection efficiency of DSSCs.
The apparent value of $\eta_{\mathrm{cc}}$ can be estimated on the basis of the $t_{r}$ and $t_{c}$ data from the following [14]:

$$
\eta_{\mathrm{cc}}=1-\frac{t_{r}}{t_{c}} .
$$

The electron transport time constants for Ca-doped $\mathrm{TiO}_{2}$ films decrease, which indicates the electrons transport faster in the Ca-doped $\mathrm{TiO}_{2}$ films than the undoped $\mathrm{TiO}_{2}$ films. This enhanced the charge collection efficiency $\eta_{c c}$ and led to higher current density $\left(J_{\text {sc }}\right)$ of DSSCs. The electron life time constants for the Ca-doped $\mathrm{TiO}_{2}$ films also slightly decrease. The electron lifetime in DSSCs is determined by the characteristic frequency peak in the low frequency $\left(f_{\max }\right)$ according to the following equation [15]:

$$
\tau_{e}=\frac{1}{2 \pi f_{\max }} .
$$

The shorter electron life time indicates the faster recombination rate in the $\mathrm{Ca}$-doped $\mathrm{TiO}_{2}$ films, and that could be attributed to impurities of Ca-doping, which acts as a charge trapping site for the electron-hole recombination. The electron lifetime decreases slightly, so we concluded 
TABLE 2: The mean electron life time $\left(t_{r}\right)$, the mean electron transit time $\left(t_{c}\right)$, and the charge collection efficiency $\left(\eta_{\mathrm{cc}}\right)$ of DSSCs based on undoped and Ca-doped $\mathrm{TiO}_{2}$ photoanodes.

\begin{tabular}{lcccrr}
\hline DSSCs & Doping/ppm & $R_{w} / \Omega$ & $t_{r} / \mathrm{ms}$ & $t_{c} / \mathrm{ms}$ & 0.0088 \\
Undoped & 0 & 7.36 & 0.0350 & 0.0290 & 0.0077 \\
Ca-1 & 20 & 7.32 & 0.0294 & 0.0059 & 0.73 \\
Ca-2 & 50 & 5.24 & 0.0290 & 0.0076 & 0.80 \\
Ca-3 & 70 & 7.27 & 0.0290 & 0.0080 & 0.72 \\
Ca-4 & 100 & 8.09 & & & 0.73 \\
\hline
\end{tabular}

that less photogenerated electrons are captured by empty trap states in the Ca-doped $\mathrm{TiO}_{2}$ films [16], and this result favors the electron transport. The improvement of electron transport ability was helpful to increase the short-circuit current density $\left(J_{\mathrm{sc}}\right)$, resulting in higher conversion efficiency.

\section{Conclusion}

In summary, the Ca-doping $\mathrm{TiO}_{2}$ nanoparticles were successfully applied as the photoanode material in DSSCs. By comparing the Ca-doping $\mathrm{TiO}_{2}$ with undoping $\mathrm{TiO}_{2}$, a faster electron transport and shorter lifetime existed for the Ca-doping DSSCs. Moreover, the higher electron transport rates of $\mathrm{Ca}$-doped $\mathrm{TiO}_{2}$ photoanode can improve the charge collection efficiency and thus lead to higher short-circuit photocurrent density of DSSCs. The best photovoltaic performance was obtained from $50 \mathrm{ppm} \mathrm{Ca-doping} \mathrm{with} \mathrm{the}$ conversion efficiency of $7.45 \%$. This value was $9.88 \%$ higher than that of the undoped device. The short-circuit current density $\left(J_{\mathrm{sc}}\right)$ was increased due to the faster electron transport in the $\mathrm{Ca}$-doped $\mathrm{TiO}_{2}$ film. We can conclude that $\mathrm{Ca}$-doped $\mathrm{TiO}_{2}$ is a better photoanode material and a more promising alternative for high efficient DSSCs than pure $\mathrm{TiO}_{2}$.

\section{Conflict of Interests}

The authors do not have any conflict of interests in their submitted paper.

\section{Acknowledgments}

We acknowledge the supported of the National Natural Science Foundation of China (Grant no. 11364014), the National Science Foundation of Hainan Province, China (Grant no. 113005), and Physics Graduate Project of Hainan Normal University (20140092102).

\section{References}

[1] H. Yu, S. Q. Zhang, H. J. Zhao, B. Xue, P. Liu, and G. Will, "High-performance $\mathrm{TiO}_{2}$ photoanode with an efficient electron transport network for dye-sensitized solar cells," The Journal of Physical Chemistry C, vol. 113, no. 36, pp. 16277-16282, 2009.

[2] F. R. Li, G. C. Wang, and Y. Jiao, "Efficiency enhancement of ZnO-based dye-sensitized solar cell by hollow $\mathrm{TiO}_{2}$ nanofibers," Journal of Alloys and Compounds, vol. 611, no. 5, pp. 19-23, 2014.
[3] H. K. Wang and A. L. Rogach, "Hierarchical $\mathrm{SnO}_{2}$ nanostructures: recent advances in design, synthesis, and applications," Chemistry of Materials, vol. 26, no. 1, pp. 123-133, 2014.

[4] M. Quintana, T. Edvinsson, A. Hagfeldt, and G. Boschloo, "Comparison of dye-sensitized $\mathrm{ZnO}$ and $\mathrm{TiO}_{2}$ solar cells: studies of charge transport and carrier lifetime," The Journal of Physical Chemistry C, vol. 111, no. 2, pp. 1035-1041, 2007.

[5] C. N. Zhang, S. H. Chen, L.-E. Mo et al., "Charge recombination and band-edge shift in the dye-sensitized $\mathrm{Mg}^{2+}$-doped $\mathrm{TiO}_{2}$ solar cells," The Journal of Physical Chemistry C, vol. 115, no. 33, pp. 16418-16424, 2011.

[6] J. Y. Zhang, Z. Y. Zhao, X. Y. Wang et al., "Increasing the oxygen vacancy density on the $\mathrm{TiO}_{2}$ surface by La-doping for dyesensitized solar cells," The Journal of Physical Chemistry C, vol. 114, no. 43, pp. 18396-18400, 2010.

[7] Q. H. Yao, J. F. Liu, Q. Peng, X. Wang, and Y. Li, "Nd-doped $\mathrm{TiO}_{2}$ nanorods: preparation and application in dye-sensitized solar cells," Chemistry, vol. 1, no. 5, pp. 737-741, 2006.

[8] J. Liu, H. T. Yang, W. W. Tan, X. Zhou, and Y. Lin, "Photovoltaic performance improvement of dye-sensitized solar cells based on tantalum-doped $\mathrm{TiO}_{2}$ thin films," Electrochimica Acta, vol. 56, no. 1, pp. 396-400, 2010.

[9] W. Guo, L. Q. Wu, Z. Chen, G. Boschloo, A. Hagfeldt, and T. Ma, "Highly efficient dye-sensitized solar cells based on nitrogendoped titania with excellent stability," Journal of Photochemistry and Photobiology A: Chemistry, vol. 219, no. 2-3, pp. 180-187, 2011.

[10] Y. N. Xie, N. Huang, S. J. You et al., "Improved performance of dye-sensitized solar cells by trace amount Cr-doped $\mathrm{TiO}_{2}$ photoelectrodes," Journal of Power Sources, vol. 224, no. 10, pp. 168-173, 2013.

[11] Z. F. Tong, T. Peng, W. W. Sun et al., "Introducing an intermediate band into dye-sensitized solar cells by $\mathrm{W}^{6+}$ doping into $\mathrm{TiO}_{2}$ nanocrystalline photoanodes," Journal of Physical Chemistry $C$, vol. 24, no. 5, 2014.

[12] M. Adachi, M. Sakamoto, J. Jiu, Y. Ogata, and S. Isoda, "Determination of parameters of electron transport in dye-sensitized solar cells using electrochemical impedance spectroscopy," The Journal of Physical Chemistry B, vol.110, no. 28, pp. 13872-13880, 2006.

[13] Q. Wang, J.-E. Moser, and M. Grätzel, "Electrochemical impedance spectroscopic analysis of dye-sensitized solar cells," The Journal of Physical Chemistry B, vol. 109, no. 31, pp. 1494514953, 2005.

[14] K.-P. Wang and $\mathrm{H}$. Teng, "Zinc-doping in $\mathrm{TiO}_{2}$ films to enhance electron transport in dye-sensitized solar cells under lowintensity illumination," Physical Chemistry Chemical Physics, vol. 11, no. 41, pp. 9489-9496, 2009. 
[15] N.-G. Park, J. van de Lagemaat, and A. J. Frank, "Comparison of dye-sensitized rutile- and anatase-based $\mathrm{TiO}_{2}$ solar cells," The Journal of Physical Chemistry B, vol. 104, no. 38, pp. 8989-8994, 2000.

[16] Y. D. Duan, N. Q. Fu, Q. P. Liu et al., "Sn-doped $\mathrm{TiO}_{2}$ photoanode for dye-sensitized solar cells," The Journal of Physical Chemistry C, vol. 116, no. 16, pp. 8888-8893, 2012. 

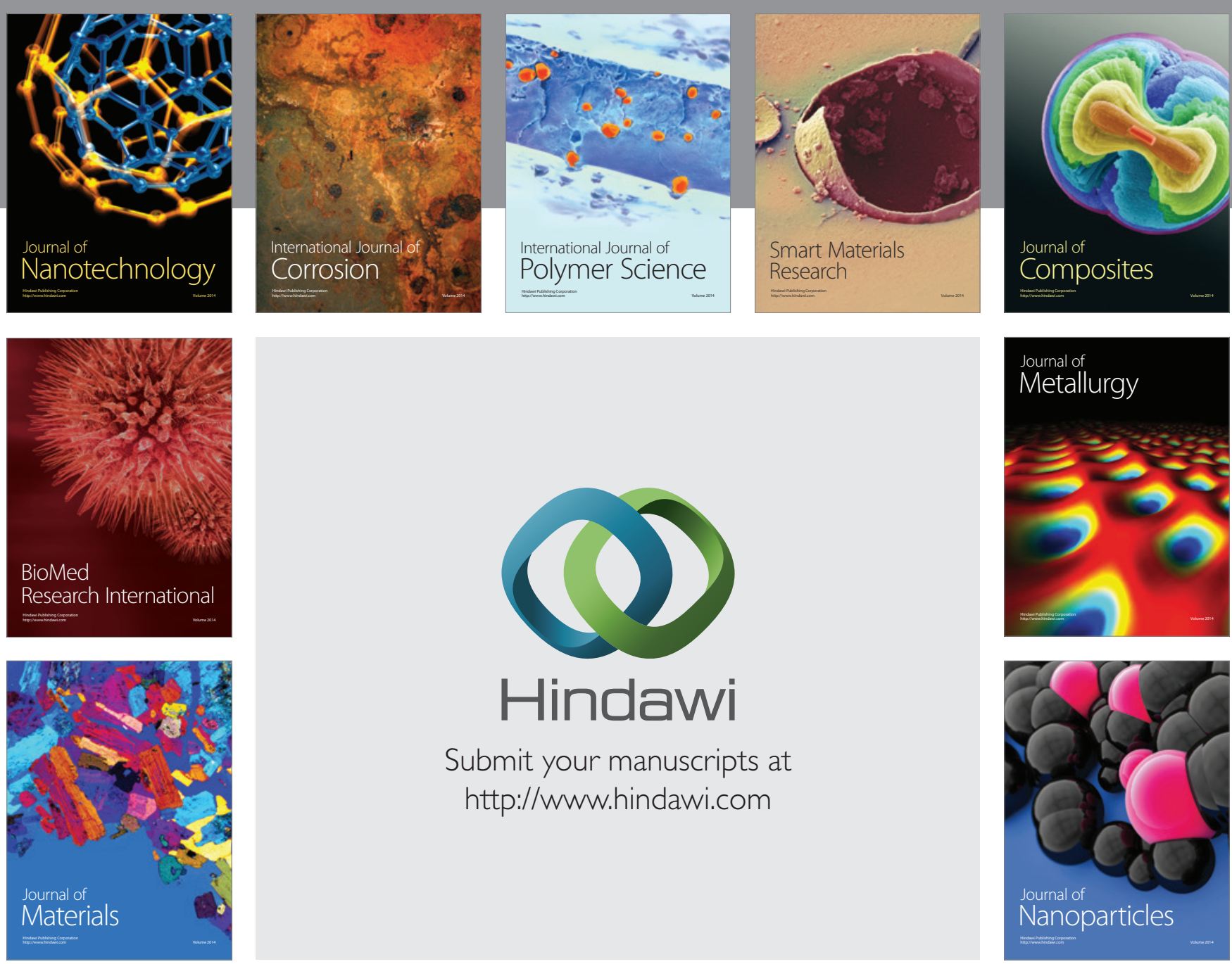

Submit your manuscripts at http://www.hindawi.com
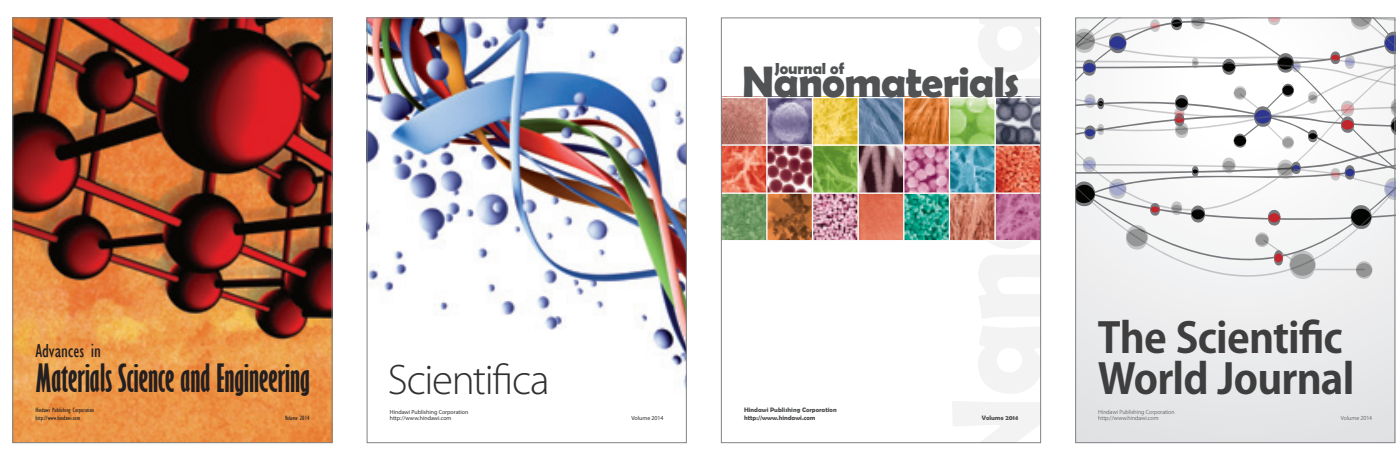

\section{The Scientific World Journal}
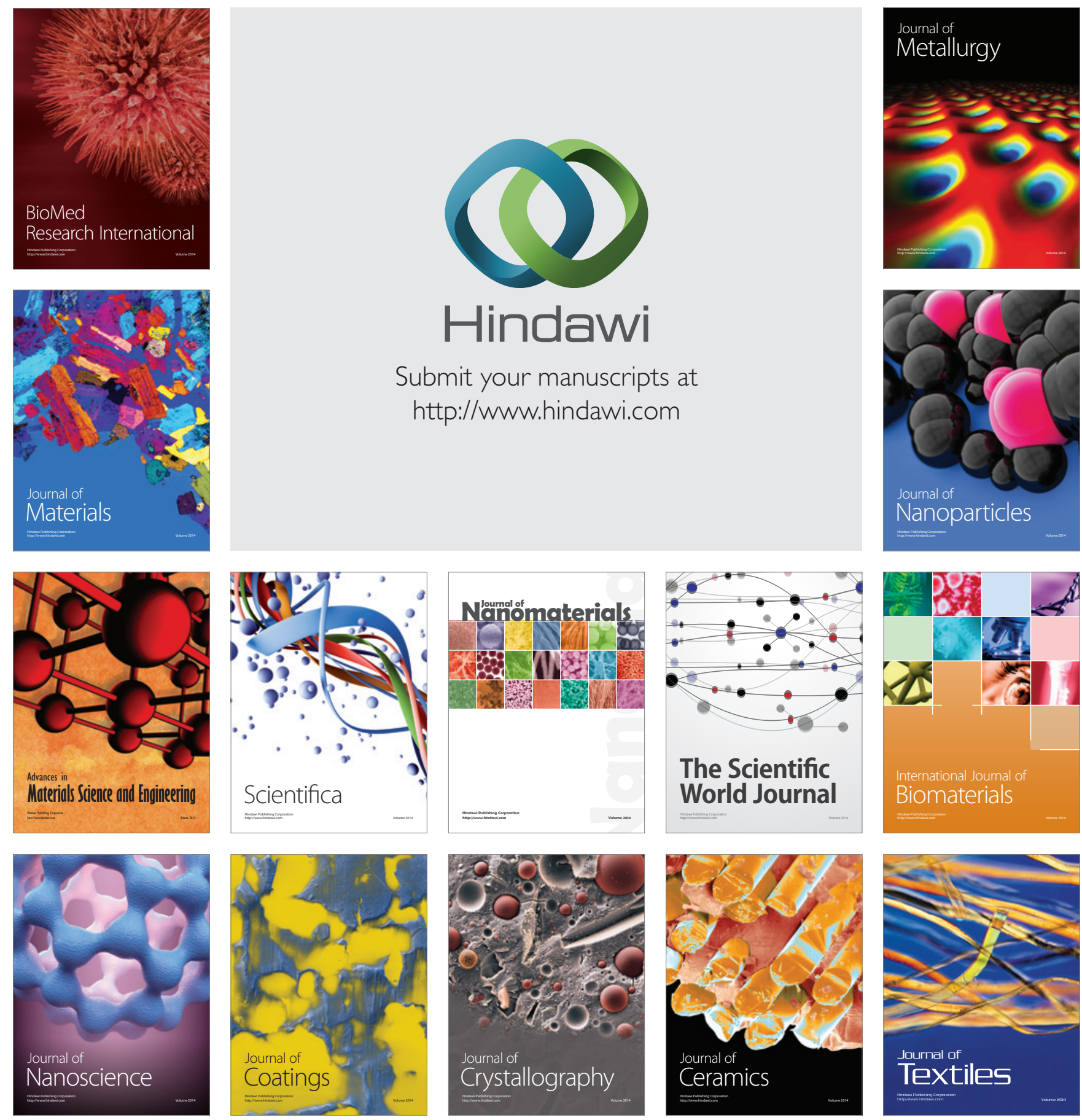